\title{
DEEP SEA FISHERIES - IMPLICATIONS IN CONSERVATION
}

\author{
L BOTHA \\ Chief Professional Officer \\ Department of Industries \\ Sea Fisheries Branch \\ Private Bag \\ Sea Point \\ 8060
}

I stand before you as what I would reluctantly like to call a crisis conservationist. In marine fisheries conservation we are exposed to the full blast of human greed. Dr Hey has referred to the unfortunate human attitudes to nature conservation. I fully share his concern. Fisheries conservation finds itself in the unenviable position of having largely to apply conservation principles to species which are more often than not in advanced stages of commercial exploitation. In this situation ethics, aesthetics and science cuts little or no ice with decision-makers. The only language which they understand is economics. Unfortunately fisheries conservation has also been hampered by the well-meant but thoroughly unscientific efforts of certain lay so-called "conservation societies". Through their admirable but purely humanistic approach to conservation, they have antagonized economically-orientated decision-makers and thereby unfortunately harmed the cause of conservation. In this regard I would like to associate myself strongly with $\mathrm{Dr}$ Vollmar, $\mathrm{Mr}$ de la Bat and numerous other speakers who have emphasized that we should put all our efforts into convincing decision-makers and others that conservation is in fact an economic proposition. In the deep-sea fisheries conservation situation, Mr Chairman, I feel that we should take special note of the emphasis placed on "utilization" or "wise use" by many previous speakers, rather than laying too much emphasis on the traditional "safeguarding" interpretation of conservation.

In this regard, Mr Chairman, I have followed with interest the evolution of the concept of nature conservation over the last few years. More recent definitions have given increasing prominence to terms such as "utilization" and "wise use" of wildlife resources. I do feel, $\mathrm{Mr}$ Chairman, that the concept of "Nature Utilization" may be easier to sell to decision-makers and the public at large, rather than the concept of "Nature Conservation" with its more traditional implications of protection purely for pleasure. Especially in developing countries, and Southern Africa is a developing area Mr Chairman, wise utilization of natural 
resources makes more sense at least initially to the ordinary people, than the comparative easthetic luxury of pure traditional conservation.

However, I do not wish to digress from my topic of marine conservation. My main purpose in drawing attention to the "new" definition of nature conservation is that my and other similar institutes can now for the first time consider themselves as having come in from the cold, so to speak. For many years marine fisheries conservation was not considered by many professionals as true conservation in the strict sense of the old definition because of the overriding importance of the commercial utilization component thereof. Marine fisheries conservation will probably always be considered as a somewhat special type of conservation since it is invariably applied to populations which are already in a state of varying degrees of exploitation. Nevertheless, I do feel that the new definition now provides some justification for my institute to consider itself as probably the largest specialized nature conservation institute of its type in Southern Africa. With a staff of more than 500, five laboratories and field stations, 12 research and fisheries patrol vessels and an operational area stretching from the Cunene River right around the coast to the southern Mocambique border, this is no hollow claim. At stake is the well-being of an industry which harvests more than 1 million metric tons of marine life valued at close on R200 million per year and an earner of valuable foreign exchange. The wise utilization of these vast living marine resources is the main purpose and function of my organization.

The Sea Fisheries institute is a branch of the South African Department of Industries, which in turn advises the Minister of Economic Affairs on Fisheries management policy. The ultimate responsibility for the conservation of marine life beyond the highwater-mark rests with the Minister. Such responsibility is exercised through the Sea Fisheries Act and regulations and various other relevant Acts, which are in turn administered by the Sea Fisheries Branch. The all important research function of the Branch is carried out by a team of 43 professional scientists qualified in the fields of physical and chemical oceanography, fisheries biology, planktology, marine acoustics, algology, marine mammology, electronic data processing, engineering and other highly specialized fields. Research projects logically relate in priority to the relative commercial importance of the various components of the fishing industry. Current priority projects in the Branch consequently entail work on the population dynamics, biology and the fisheries, of in the first instance, species such as pilchards, anchovies, mackerel and maasbanker, which form the basis of the massive pelagic sector of the fishing industry. This sector of the industry alone accounts for more than $80 \%$ of South Africa's annual harvest from the sea and has secured our coveted, although in some quarters dubious, position as the second largest fishmeal exporter in the world after Peru, and one of the major fishing nations. The catastrophic collapse of the Californian pilchard 
fishery because of overfishing during the nineteen fifties, and the recent virtual collapse of the world's largest single species fishery for the Pcruvian anchovy because of a combination of heavy fishing and adverse environmental conditions, have underlined the tremendous importance of a sound ecological approach to such animals. In fact, despite energetic efforts to save it, the South African pilchard fishery also collapsed during the late nineteen sixties. The vast pilchard resource off the South West African coast is now the last major fishery of its kind in the world and no effort is spared to keep it that way. Research staff of the Branch have pioneered population abundance estimates by means of inter alia airborne survey methods, which have yielded much quicker results than the traditional somewhat more accurate but time-consuming methods of population estimates by means of recruitment, mortality, growth and fishing effort studies. Particular attention is paid to environmental parameters which have a profound influence on stock availability and abundance. The fishery is currently managed by means of a catch quota system, limits on the number of processing factories, hold capacity and number of vessels, a closed season and closed areas. Early results seem to confirm that the recent decline in the SWA pilchard fishery has been arrested in this way and provide considerable optimism for the future.

Other projects entail work on South Africa's important rock lobster resources, including an assessment of the abundance of the newlydiscovered rock lobster resource off Port Elizabeth. Early indications are that this new stock has an extremely slow growth rate and that its potential catch may therefore be considerably lower than the optimistic expectations created by initial high catch rates. Pending more concrete results about potential yields, this new fishery is currently managed on a permit basis and foreign vessels have been ousted from the fishery by extending South Africa's jurisdiction over this sedentary continental shelf species which occurs outside our present fishing zone, in terms of an existing Geneva convention which provides for such action. South Africa's traditional coastal rock lobster fishery is in a good state and is managed successfully by means of a catch quota, sanctuaries, a minimum permissible fish size and a ban on the catching of soft-shelled animals and berried females. The rock lobster industry itself is also subjected to license limitation and strict landing, transport, processing and quality control restrictions.

Other research projects entail work on various bait organisms such as mussels, oysters, red-bait, scallops and abalone, while considerable attention has lately also been focussed on whales and particularly on seals. You may know that the last South African whaling company has recently ceased operations altogether and a long South African tradition as a whale-catching country has thus come to an end. The reason for this closure has mainly resulted from a very strict catch quota system now introduced by the International Whaling Commission (IWC) as a result of years of overexploitation of certain whales by various countries. South 
Africa is a member of the IWC and scientists from the Sea Fisheries Branch have and are still taking an active part in the scientific work of the Commission.

While no tuna fishery as such exists in South Africa, the country is an active member of the International Commission for the Conservation of Atlantic Tunas (ICCAT). Scientists from the Branch attend regular meetings of this Commission and contribute data to the population assessments of the stocks of the various highly-migratory tunas of the Atlantic Ocean.

Apart from the foregoing, the Sea Fisheries Branch also undertakes studies on the physical/chemical aspects of our oceans including work on pesticides and marine pollution. However, since it is not my intention at the present time to inform you fully of all the various and wide ranging projects in the field of marine conservation in current progress at the Branch, the foregoing brief yet inadequate outline will have to suffice. I would, however, now like to come to the main topic of my talk namely the implications of conservation in deepsea fisheries.

You may be aware of the fact that some fifteen different foreign countries are most actively removing almost a million tons of fish from the waters around South- and South West Africa each year. This development started on a modest scale in 1962 when Spanish and Japanese trawlers, driven thereto by extremely low catch rates resulting from years of heavy fishing on their home grounds, first probed and then arrived in force on the then rich Southeast Atlantic fishing grounds. Their phenomenal catch successes soon became known in fishing circles and at present some 300 huge, modern stern-trawlers drag up tons and tons of fish from the cold and fertile waters of the southern African westcoast. Their main target is the Cape hake (or stockfish) which is the dominant fish species in the area. Estimates of maximum sustainable yield for hake provide a figure of some 950000 tons per year, but catches have in recent years exceeded 1 million metric tons. These high catches in combination with declining catch rates have led to serious national and international concern. This concern culminated in a meeting of plenipotentiaries which was held under the auspices of the Food and Agriculture Organization of the UN in Rome during 1969. The result of this meeting was a Convention on the Conservation of the Living Resources of the Southeast Atlantic Ocean, in which the participating nations agreed to take certain prescribed steps to conserve the marine populations in the area. The Convention became a reality in 1972 when the newly-established International Commission for the Southeast Atlantic Fisheries (ICSEAF) met for the first time at its headquarters in Madrid to give effect to the terms of the Convention.

Members of ICSEAF currently comprise South Africa, Spain, the USSR, Portugal, Japan, Cuba, Poland, Israel, Bulgaria, France, Belgium, Italy and the German Democratic Republic. The Commission meets every second year in Madrid where it considers the scientific 
advice of its permanent Scientific Advisory Council. Scientists from member countries, including scientists from the Sea Fisheries Branch, participate actively in the work of the Council. The scientific work entails the usual biological and population dynamics studies with the main aim of establishing optimum catch levels.

The difficulty of course with deepsea fisheries conservation is that operations are conducted in international waters beyond the jurisdiction of coastal state territorial or fisheries waters. For this reason it is not yet possible for a coastal state such as South Africa to unilaterally prescribe and enforce adequate conservation measures for the living marine resources far off its own coasts. I say this is not yet possible, because certain recent developments will in due course in fact make this a possibility. This brings us to the core of our present discussion on the implications in conservation of deepsea fisheries. The existing set-up of international deepsea fisheries conservation provides no adequate protection of the exploited stocks. It is left to the lengthy, cumbersome and often undecisive deliberations and actions of international commissions such as ICSEAF, IWC and others to agree to conservation measures. These international fisheries commissions have no legal powers and can only offer advice to governments, which may or may not be endorsed and accepted in practice by the governments concerned, depending on their respective interests. The result is that, despite the very active existence of a multitude of such fisheries commissions throughout the world, few if any of them have achieved real conservational successes. Many conservation measures have in fact been formally accepted, but the practical implementation and enforcement thereof remains a largely unsolved problem. Hence we witness the so-called "fish war" between the United Kingdom and Iceland for example, which has had serious repercussions even in jeopardizing their future participation in the North Atlantic Treaty Organization.

It is precisely this dissatisfaction with existing international deep-sea fisheries commissions which has prompted many countries to press for exclusive coastal state control of fisheries. You may know that such deliberations are at present in progress at the UN Law of the Sea Conference. As far as fisheries conservation is concerned, wide consensus exists at the conference that the conservation and management of living marine resources will in the future be the exclusive responsibility of coastal states up to 200 nautical miles off their respective coasts. While some countries have doubts about the competence and expertise with which certain countries may exercise such a responsibility, most are convinced that it will for the first time in history provide for the full and adequate protection of coastal fisheries. Highly migratory and wideranging species such as tuna and whales will still, however, by their very nature be the responsibility of international commissions.

Despite these developments and despite the dissatisfaction with existing international fisheries commission, an organization such as 
ICSEAF has nevertheless taken significant steps to conserve fish stocks. So for example the member countries of ICSEAF recently unanimously adopted and implemented a minimum mesh-size in the trawlnets of their vessels fishing in the Southeast Atlantic Ocean. It furthermore implemented a joint international inspection scheme to enforce this regulation. South Africa, through the Sea Fisheries Branch, is a leading and active participant in this scheme which, with 13 countries participating, must surely be one of the largest conservation schemes in operation at this moment in our area. South African fisheries inspectors of the Sea Fisheries Branch have during the past year boarded some 180 Japanese, Russian, Bulgarian, Polish and South African fishing vessels on the high seas to inspect their nets in terms of the scheme of joint international enforcement. Only 19 (or 10\%) contraventions have been reported, which is considered as very good for a conservation scheme of this nature, scope and complexity. Clearly the will to succeed is there, which augurs well for the future.

It is this kind of co-operative and positive development in international deep-sea fisheries conservation which gives some hope for the continued existence of international fisheries commissions, despite the looming exclusive coastal state jurisdiction of the future. This is then, in summary, how I see the implications in deep-sea conservation in the future, namely the continued existence of international commissions, which would act mainly as a forum for the collective sharing of scientific problems and the transfer of marine scientific technology, coupled with and perhaps supplementing full and exclusive coastal state jurisdiction over the vast and valuable living resources of the world oceans. There is a considerable amount of urgency to protect many already overexploited stocks, but as far as a deep-sea conservation is concerned, I am optimistic that man will rise to the challenge and that the new order will ensure adequate protection of our marine wildlife. 